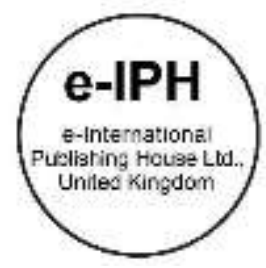

\title{
Speech Acts in Trials of Underage Sexual Criminal Case
}

\author{
Amirah Ahmad, Norizah Ardi, Rozaimah Rashidin \\ Akademi Pengajian Bahasa, Universiti Teknologi MARA, 40450 Shah Alam, Selangor, Malaysia \\ amirah1275@uitm.edu.my, norizah@uitm.edu.my,rozai451@uitm.edu.my \\ Tel of 1st Author: +6012-7355147
}

\begin{abstract}
Language usage in a court trial of a criminal case is usually associated with utterances that lead to justification of the imposed punishment for the offender. Utterances of justification are usually categorized as a performative speech act. Each utterance can be categorized into five types of speech, namely representatives, directives, commissive, expressive, and declaratives. This descriptive study uses the text analysis technique, by analysing the utterance delivered in the court trial. The findings showed that mostly the Deputy Public Prosecutor and the advocates are using the directive speech act whereas the OKT and the witnesses are using representative speech acts.
\end{abstract}

Keywords: speech acts; court trial; under age criminal case

eISSN: 2398-4287 @ 2021. The Authors. Published for AMER ABRA cE-Bs by e-International Publishing House, Ltd., UK. This is an open access article under the CC BYNC-ND license (http://creativecommons.org/licenses/by-nc-nd/4.0/). Peer-review under responsibility of AMER (Association of Malaysian Environment-Behaviour Researchers), ABRA (Association of Behavioural Researchers on Asians) and cE-Bs (Centre for Environment-Behaviour Studies), Faculty of Architecture, Planning \& Surveying, Universiti Teknologi MARA, Malaysia.

DOI: https://doi.org/10.21834/ebpj.v6iSI5.2922

\subsection{Introduction}

Speech acts refer to a language performance that supports a pragmatic proposition which is a dual function namely constative and performative functions. Constative is an utterance that conveys literally, whereby performative refers to the intention of the utterance which been delivered to effects hearers' response. When a person makes an utterance, it is also doing something (Austin, 1962). Therefore, a speech act is an utterance that implies certain meaning and action that needs to be interpreted the intention and purpose based on the aspects of the speech situation. Aspects of the speech situation in a courtroom trial involve interrogation and crossexamination process. A person who is found guilty will be convicted and stated his sentence clearly. However, during the trial, the accused also called Orang Kena Tuduh (OKT) (in Malay terminology) will be given the chance to defend him/herself, while the advocate and public prosecutor will take advantage of the situation to prove/point out either the accused is guilty or not.

Courtroom trials are one of the authentic resources to extract relevant information in giving a vivid picture of the case. Catoto (2017) mentioned that courtroom proceedings provide the judge with profound knowledge in giving the final verdict. There will be different types of questions and responses employed during the cross-examination. Besides that, the intention of utterances being said in a legal context will have a different connotation and interpretation from the daily speech events. In the investigating legal context, judges and lawyers frequently comment that in some cases in criminal investigations there are not clear or proved evidenced to find solutions for the crimes and sometimes some cases are incriminated wrongly, and missteps might happen in the courts (Amin \& Biook, 2014). It shows that the ambiguity during interrogation and attestation can happen during the cross-examination. The uncertainty will lead to the injustice judgement if the sentence being charged does not coincide with the misconduct. Therefore, this study aims to interpret the speech act functions during cross-examination of the courtroom trial of the underage sexual criminal case with the purpose of understand the implying meaning of the utterances.

elSSN: 2398-4287 @ 2021. The Authors. Published for AMER ABRA cE-Bs by e-International Publishing House, Ltd., UK. This is an open access article under the CC BYNC-ND license (http://creativecommons.org/licenses/by-nc-nd/4.0/). Peer-review under responsibility of AMER (Association of Malaysian Environment-Behaviour Researchers), ABRA (Association of Behavioural Researchers on Asians) and cE-Bs (Centre for Environment-Behaviour Studies), Faculty of Architecture, Planning \& Surveying, Universiti Teknologi MARA, Malaysia.

DOI: https://doi.org/10.21834/ebpj.v6iSI5.2922 


\subsection{Speech Act in Cross-examination}

In cross-examination, the dominant speech act functions are questioning or interrogating, achieved through questions by the advocate and public prosecutor (Lane, 1990; Eades, 2000 \& Catoto; 2017). Therefore, this paper aims to show a variety of other speech act functions are achieved, and that these functions vary in their pragmatic significance depending on the fact of their occurrence in the cross-examination phase of trials. Danet (1980) mentioned legislation discourse contains diverge speech act functions namely representative, commissive, expressive, directive and declarative. According to the speech act functions, speech is a kind of action. When someone says something, he does something. Certainly, when a judge or a court says something, he performs some acts like uttering or writing some sentences.

The cross-examination phase is a platform for the accused to present testimony favourable. The discourse implies that the examiner and the witness, by and large, work together to develop a case theory through their question-answer interaction. Thus, for this reason, that direct examination has been characterized as the phase of court trials that is pleasant to the witness (Danet, 1980; Lane, 1990; Luchjenbroers, 1993; Eades, 2000). The direct examination phase provides the opportunity for witnesses to present testimony favourable to the party that calls the witness. During this phase, utterances aim for attestation and defence. The utterance in speech act can be divided into two namely constative and performative (Austin, 1962). Attestation and defence statements usually refer to a performative speech act. Constatives statement is either true or false, and did not imply any because it is based on a fact (e.g. "Today's weather is fine), meanwhile a performatives statement is neither true nor false, and it implies action in the saying of the utterance (depending on context) (e.g. "This cheesecake is mouth-watering" - can be interpreted as an appraisal or asking for another slice of cheesecake). Performatives utterance is closely related to the speaker's intention and action.

\subsection{Literature Review}

Previous studies show that the study of speech acts in Malaysia already started two decades ago and cover various scenes and texts. Ahmad Mahmood (1998) focused on questioning-answering speech acts in Salina by A. Samad Said based on the speech act theory proposed by Austin (1962) and Searle (1969). Ahmad Mahmood (2000) expanded the study and focusing on questioning speech act based on situational and contextual analysis. The same framework proposed by Austin (1962) and Searle (1969) also has been utilised by Maslida and Karim (2015) to analyse the communications functions in Facebook's comments. Even though there were many scholars discussed speech acts in various contexts such as in Syariah courtroom proceedings (Rohaidah, 2004), tourist communications events (Ruth Ong Lok Tik, 2005), counselling sessions (Wan Robiah, Hamidah \& Siti Marina, 2010), Friday's prayer sermons (Abd. Ganing, 2018) and tabloid discourse forum (Abd. Ganing, Ab. Razak \& Riduan, 2019), but the study of speech act in courtroom trial specifically in an underage criminal case are still under research compare with the scholars from abroad (Lane, 1990; Eades, 2000; Farinde, 2009; Amin \& Biook, 2014; Catoto, 2017).

\subsection{Speech Acts Concept}

According to speech act theory, there are many things that speakers can do by uttering words and sentences. Asking questions or giving explanations are examples of speech acts functions. According to Yule (1996), when a person conveys something through a certain utterance, it is called a speech act. Conceptually, a speech act is an utterance that contains functions. In a court trial, the functions of each utterance will be interpreted and analysed based on the speech acts theory proposed by Austin (1962) and Searle \& Vanderveken (1985). Austin (1962) made a further distinction between three aspects of utterances: locutionary act refers to the making of sounds, the physical utterance of what is literally said; illocutionary force of an utterance is the work it accomplishes in being uttered in a specific context (most of the pragmatists agree the functions of speech acts identified at this state), and perlocutionary effect is the effect on the hearer.

\subsection{Types of Speech Acts and its Functions}

There are several numbers scholars who suggest the types and functions of speech acts (Austin,1962; Searle, 1969; Bach \& Harnish, 1979; Danet, 1980). This study is analysed based on speech acts' types and functions proposed by Searle \& Vanderveken (1985) because it is more comprehensive to examine the language usage in a court trial (Refer Table 1).

Table 1. Types of speech acts and their function (Searle \& Vanderveken, 1985)

\begin{tabular}{|l|l|l|}
\hline $\begin{array}{l}\text { Types of Speech } \\
\text { Acts }\end{array}$ & Description & Functions \\
\hline Assertive & $\begin{array}{l}\text { The assertive speech act is to say how things } \\
\text { are. The speaker presents a proposition as } \\
\text { representing an actual state of affairs in the } \\
\text { world. }\end{array}$ & $\begin{array}{l}\text { assert, claim, affirm, state, deny, disclaim, assure, argue, } \\
\text { rebut, inform, notify, remind, object, predict, report, retrodict, } \\
\text { suggest, insist, conjecture, hypothesize, guess, swear, testify, } \\
\text { admit, confess, accuse, blame, criticize, praise, complain, } \\
\text { boast and lament }\end{array}$ \\
\hline Commissive & $\begin{array}{l}\text { The commissive speech act is to commit the } \\
\text { speaker to do something in the future. The } \\
\text { speaker commits himself to carry out the } \\
\text { course of action represented by the } \\
\text { propositional content. }\end{array}$ & $\begin{array}{l}\text { commit, promise, threaten, vow, pledge, swear, accept, } \\
\text { consent, refuse, offer, bid, assure, guarantee, warrant, }\end{array}$ \\
\hline Directive & $\begin{array}{l}\text { The directive speech act is to try to get other } \\
\text { people to do things. The speaker attempts to }\end{array}$ & $\begin{array}{l}\text { direct, request, ask, urge, tell, require, demand, command, } \\
\text { order, forbid, prohibit, enjoin, permit, suggest, insist, warn, }\end{array}$ \\
\hline
\end{tabular}




\begin{tabular}{|l|l|l|}
\hline & $\begin{array}{l}\text { get the hearer to carry out the course of action } \\
\text { represented by the propositional content. }\end{array}$ & $\begin{array}{l}\text { advise, recommend, beg, supplicate, beseech, implore and } \\
\text { pray }\end{array}$ \\
\hline Declarative & $\begin{array}{l}\text { The declarative speech act is to change the } \\
\text { world by saying so. The speaker brings about } \\
\text { the state of affairs represented by the } \\
\text { propositional content solely in virtue of his } \\
\text { successful performance of the speech act. }\end{array}$ & $\begin{array}{l}\text { declare, resign, adjourn, appoint, nominate, approve, confirm, } \\
\text { disapprove, endorse, renounce, disclaim, denounce, } \\
\text { repudiate, bless, curse, excommunicate, consecrate, christen, } \\
\text { abbreviate, name and call }\end{array}$ \\
\hline Expressive & $\begin{array}{l}\text { The expressive speech act is to express } \\
\text { feelings and attitudes. The speaker expresses } \\
\text { some psychological attitude about the state of } \\
\text { affairs represented by the propositional } \\
\text { content. }\end{array}$ & $\begin{array}{l}\text { apologize, thank condole, congratulate, complain, lament, } \\
\text { protest, deplore, boast, compliment, praise, welcome and } \\
\text { greet }\end{array}$ \\
\hline
\end{tabular}

The description proposed in speech act theory as shown in Table 1 are based on isolated examples and define an ideal or prototypical use of the speech act. Thus, the utterances delivered in the court trial is categorized based on the five types of speech act theory stated in Table 1.

\subsection{Data and Methodology}

Pragmatic is the study of how language is used to express meaning in context. Hence, the type of data used in this study is utilized from authentic written data which is a transcription of court trials (courtroom proceedings). This study employed a qualitative approach where the data is utilized from the courtroom proceedings of an underage criminal case settled in 2015. Out of 223-pages courtroom proceeding, only just 10\% of the proceeding (23 pages) was used in this study which involved 12 trials between 8th November 2013 until 18th March 2015.

The trials involved a victim of a 13-years old girl that has been raped by nine individuals. The data is analysed by the utterances delivered by Judge (J), Deputy Public Prosecutors (DPP), advocates (A), investigation officer (IO), witnesses (W) and the accused (orang kena tuduh-OKT). Descriptive analysis of the data is based on Austin (1962) aspects of speech acts and types of speech acts and their functions by Searle \& Vanderveken (1985). The utterances in the courtroom proceeding are categorized into five types of speech acts namely assertive, directive, commissive, declarative and expressive. Subsequently, the functions of each utterance are identified based on Austin (1962) and Searle \& Vandeverken (1985).

\subsection{Findings}

As mentioned earlier, the utterances can be categorized into two speech act categories which are constative and performative. Constative mostly (though not necessarily) have the form of declarative sentences, they refer to the act of saying something, and, as mentioned above, they are truth-evaluable or at least purport to describe reality (cf. Petrey 1990:4). Meanwhile, performative typically thought of (I do, I promise, etc.) are neither true nor false, though they may imply sentences that are true or false. Thus, performatives act the saying of them.

\subsection{Assertive}

The utterance in example (1) indicates a speech situation in which the Deputy Public Prosecutor (DPP) informed the court that the documents are already been submitted through the linguistics marker 'telah diserahkan'. The speech situation shows that the advocates (A) share linguistic conventions because the utterances do not involve any action to the hearer.

(1)

\begin{tabular}{|ll|l|}
\hline DPP & $:$ & Semua dokumen telah diserahkan kecuali laporan perubatan rasmi dan laporan kimia. (Constative) \\
A & $:$ & Saya tiada bantahan. \\
\hline
\end{tabular}

Locutionary act

Illocutionary force

\section{Perlocutionary effect}

The DPP said all documents have been submitted except the official medical report and forensic report.

Types of speech acts - assertive

Functions - to inform the court about the reports

The locutionary act in example (1) illustrates the facts delivered by DPP regarding the status of the reports; the illocutionary force of the utterance is to inform the court that he had submitted the document requested. The advocate response without objection is the perlocutionary effect of that particular utterance. The utterance is referred to as the constative speech act because it is only stated the fact that the documents already being submitted except the official medical report and forensic report.

The other example of assertive speech act can be identified through the linguistic marker 'pernah lakukan' in data (2). The utterance in example (2) indicates a speech situation in which the witness (W4) mentioned that she had sex before with her previous boyfriend so as to answer the question by the advocates. The speech situation shows that the advocates $(\mathrm{A})$ tried to get a clear picture of the situation between the W4 and the accused by asking a question implicitly regarding the status of virginity of the W4. 


\begin{tabular}{|l|c|l|}
\hline A & $:$ & Cadangkan awak tahu koyakan lama disebabkan oleh apa? \\
W4 & $:$ & Saya pernah lakukan hubungan seks dengan bekas teman lelaki saya. (Constative) \\
\hline
\end{tabular}

Locutionary act

Illocutionary force

Perlocutionary effect
The W4 utter a statement that she had sex before with her previous boyfriend.

Types of speech acts - assertive

Functions - to admit the status of her virginity

The court and the advocate received the statement given.

The locutionary act in data (2) shows that the W4 utter an utterance to answer the question given by the advocates; the illocutionary force of the utterance is to admit to the court and the advocates that she had sex before with her previous boyfriend. This data shows that the phrase 'pernah lakukan' is functioning as a confession by the W4. In this particular situation, usually, the court and the advocate acknowledge the statement given by the W4 as part of the interrogation process. The utterance is referred to as a constative speech act because the fact states that the W4 had sex before the incidents happened.

\subsection{Directive}

The examples in data (3) contain directives speech act by the linguistic marker 'pohon'. The DPP uttered a request for a new date for submission from the court because the documents have yet been prepared. The speech situation shows the judge share the same context with the DPP and know the document that has been referred to.

(3)

\begin{tabular}{|l|l|l|l}
\hline DPP & $:$ & Dokumen belum disediakan. Pohon tarikh lain untuk serahan. (Performative) \\
$\mathrm{J}$ & $:$ & TPR serah dokumen di bawah s.51A 2 ming \\
\hline
\end{tabular}

Locutionary act Illocutionary force

Perlocutionary effect
The DPP said that documents have yet been prepared.

Types of speech acts - directive

Functions - to request a new date for submission

: The judge gives two weeks before the hearing date.

The locutionary act in data (3) shows that the DPP state that the documents have yet been prepared and make an utterance to request; while the illocutionary force of the utterance is to request a new date for submission; and the perlocutionary effect of the utterance is the request has been approved by the judge and the DPP have to submit the documents within two weeks before the trials. The utterance by the DPP is referred to as performative because it is an utterance that consists of a request from the other party involved in the speech event.

\subsection{Commissive}

The utterance in data (4) shows an example of a commissive speech act which indicates a speech situation between the judge and witness before the cross-examination started. The judge asked the witness to sworn after understanding the consequences of the process. The speech situation shows that the witness understands the statement uttered by the judge and make a sworn through linguistic marker 'bersumpah' to show her commitment.

(4)

\begin{tabular}{|lll|}
\hline $\mathrm{J}$ & $:$ & Faham angkat sumpah cakap benar? \\
W4 & $:$ & Kena angkat sumpah dan kena cakap benda yang betul. \\
$\mathrm{J}$ & $:$ & SP4 memahami soalan dan layak angkat sumpah. \\
W4 & $:$ & Saya (nama penuh) bersumpah saya akan bercakap benar tiada apa-apa yang benar melainkan yang \\
& benar belaka. (Performative) \\
\hline
\end{tabular}

\section{Locutionary act} Illocutionary force

\section{Perlocutionary effect}

The witness said that he will say the truth.

Types of speech acts - commissive

Functions - to sworn to declare the truth.

: The judge gives an order to continue the cross-examination.

The locutionary act in data (4) shows that the witness will say the truth during the cross-examination process; the illocutionary force of the statement is to sworn to declare the truth of any statement that has been said, and the perlocutionary effect of the utterance is the judge proceed with the cross-examination. The utterance by the witness is referred to as performative because it is a commitment made by the witness towards the court for saying the truth.

\subsection{Expressive}

Expressive speech act can be found in data (5) which indicates the speech situation between the advocates and the witness during the cross-examination. The linguistic marker 'takut' is referred to as an expressive speech act which means the witness is fear to scream. The speech situation shows that the witness answers the question that has been asked by the advocates. 
(5)

\begin{tabular}{|l|l|l|}
\hline A & $:$ & Kenapa tak jerit? \\
W4 & $:$ & Saya takut nak jerit. (Performative) \\
\hline
\end{tabular}

Locutionary act Illocutionary force

The witness answers the question given by the advocates.

Types of speech acts - expressive

Functions - fear to scream

Perlocutionary effect

: The advocates continue the cross-examination with another question.

The locutionary act in data (5) shows that the witness utters a statement that she is fear to scream with the intention of answering the question by the advocates during the cross-examination; the illocutionary force of the statement is to express her feelings which is fear to scream, and the perlocutionary effect of the utterance is the advocates carried out the cross-examination process with another question. The utterance by the witness is referred to as performative because it is an expressive thought that she is distressed to scream even though she is scared of the situation.

\subsection{Declarative}

The utterance in data (6) shows an example of a declarative speech act which consist of a speech situation between the advocates, DPP and the judge. The judge makes a declarative speech act through the linguistic marker 'kes diteruskan' so as to continue the crossexamination process. Both parties (advocates and DPP) understand the whole speech event after the declaration has been made by the judge.

(6)

\begin{tabular}{|l|c|l|}
\hline A & $:$ & Encik (nama penuh) b/p OKT2 hadir. Encik (nama penuh) peguam OKT 1 tak dapat hadir. Pohon reserve \\
cross. \\
DPP & $:$ & Bantah reserve cross, tidak adil kepada mangsa. \\
$\mathrm{J}$ & $:$ & Kes diteruskan. Boleh cross kemudian. (Performative) \\
\hline
\end{tabular}

Locutionary act Illocutionary force

\section{Perlocutionary effect}

The judge stated to further the cross-examination.

Types of speech acts - declarative

Functions - disapprove the request from the advocates

The advocates continue the cross-examination with another question.

Locutionary act of the data (6) shows that the judge stated to further the cross-examination; the illocutionary force of the utterance is to disapprove the request from the advocates to reserve a cross (postponed) the trial because the other advocates could not present on behalf of OKT1, and the perlocutionary effect is the cross-examination been continue. The utterance by the judge is referred to as performative because it is a declarative statement and involved an obligation from both parties involved during the cross-examination.

\subsection{Discussion}

The significance of the speech act functions in a court trial is more cumbersomely but more accurately. The findings showed that all five types of speech acts are found in the trial and both constative and performative utterances exist in the court trial of an underage sexual criminal case.

\subsection{Speech Acts in Trials of Underage Sexual Criminal Case}

Table 2 below shows the type of speech acts identified in the data.

Table 2. Frequency of each type of speech acts and functions identified in the data

\begin{tabular}{|l|l|l|}
\hline Types of Speech Acts & Functions & Frequency \\
\hline Assertive & inform & 16 \\
& report & 7 \\
& agree & 8 \\
& suggest & 5 \\
& confirm & 24 \\
& admit & 1 \\
& explain & 10 \\
& deny & 5 \\
& narrate & 1 \\
& state & 3 \\
& swear & 1 \\
\hline Commissive & promise & 1 \\
\hline Directive & request & 23 \\
& direct & 5 \\
& ask & 38 \\
& forbid & 1 \\
& require & 4 \\
\hline
\end{tabular}




\begin{tabular}{|l|l|l|}
\hline Declarative & disapprove & 1 \\
& declare & 1 \\
& adjourn & 1 \\
\hline Expressive & fear & 1 \\
& helpless & 1 \\
& doubt & 1 \\
\hline Total & & 159 \\
\hline
\end{tabular}

As can be seen from Table 2 above, there are 159 speech acts identified in the data. Assertive speech act shows the highest utterances were used in courtroom proceedings with a total number of 80 utterances followed with the directive (71), declarative (3), expressive (3) and commissive (2). Overall, these results indicate that assertive and directive speech acts are the most common utterances that have been used in courtroom trials. Table 2 also shows that, in the courtroom trial of an underage criminal case, the speech act of questioning (in this context labelled as ask) is not the only speech act function that has been used during the crossexamination. Interestingly, this finding contrasts with the previous studies (Danet, 1980; Lane, 1990; Luchjenbroers, 1993; Eades, 2000) because normally during the cross-examination, directive speech acts are the dominant utterance compared with assertive speech acts. Mostly the directive speech acts are uttered by the DPP and the advocates because both parties normally make a request and asking questions throughout the trial, whereas the OKT and the witnesses favour using assertive speech acts to answer all questions given during the cross-examination.

\subsection{Conclusion \& Recommendations}

In conclusion, cross-examination during the trial of an underage criminal case shows a significant usage of speech acts based on the role played by the speakers. This study shows that during the interrogation process, witnesses tend to use assertive speech act to inform, confirm and explain their statement which eventually helps the DPP and advocates take note of the necessary information. Although this study may show significant findings, future research on courtroom trials could focus on other underage sexual criminal cases such as incest, sodomy, cybersex, sexual assault/harassment and child pornography.

\section{Acknowledgements}

This study was conducted under the Fundamental Research Grant Scheme (FRGS/1/2017/ SSI0 /UiTM/02/2) sponsored by the Ministry of Higher Education, Malaysia. Researchers would like to express their deepest gratitude to Universiti Teknologi MARA and the Ministry of Higher Education, Malaysia for the opportunity given.

\section{References}

Abdul Ganing Laengkang. (2018). Analisis Lakuan Bahasa Terhadap Teks Khutbah Jumaat Negeri Selangor. In Jurnal Hal Ehwal Islam dan Warisan Selangor, 2 (1), 1 18.

Abd Ganing Laengkang, Ab Razak Ab Karim \& Riduan Makhtar. (2019). Lakuan Bahasa Kritikan Dalam Forum Wacana Sinar Harian. In Jurnal Melayu, 18 (2), $147-163$.

Ahmad Mahmood Musanif. (1998). Tanya-jawab dalam novel "Salina" karangan A. Samad Said: satu kajian berdasarkan teori lakuan pertuturan. PhD Dissertation, Universiti Malaya.

Ahmad Mahmood Musanif. (2000). Konsep pertanyaan berdasarkan teori lakuan pertuturan Melayu. In Jurnal Bahasa, 44 (12), 1318-1329.

Amin Mohamadzadegan Khoyi \& Biook Behnam. (2014). Discourse of Law: Analysis of Cooperative Principles and Speech Acts in Iranian Law Courts. Asian Journal of Education and e-Learning, 2 (4), 312-322.

Austin, J. L. (1962). How to do Things with Words. Cambridge: University Press.

Cohen, A.D. (1996). Speech acts. In. Hornberger, N. H. \& McKay, S. L. (Ed.) Sociolinguistics \& Language Teaching. Cambridge: Cambridge University Press.

Catoto, Jerson S. (2017). On Courtroom Questioning: A Forensic Linguistic Analysis. In IOSR Journal of Humanities And Social Science, 22 (11), 65-97

Danet, B. (1980). Language in the Legal Process. In Law and Society, 14(3), 447-467.

Eades, D. (2000). I don't think it's an answer to the question: Silencing Aboriginal witness in court. In Language in Language, 29,169-195. Cambridge: Cambridge University Press.

Farinde, R. O. (2009). Forensic linguistics: An introduction to the study of language and the law. Muenchen: Lincom Europa.

Lane, C. (1990). The sociolinguistics of questioning in district court trial. In B. Allan, \& J. Holmes, (Eds.) New Zealand ways of speaking English p. 221-251. Cleredon: Multilingual Matters.

Luchjenbroers, J. (1993). Pragmatic inference in language processing. PhD Dissertation. La Trobe University. 
Maslida Yusof \& Karim Harun. (2015). Analisis lakuan tutur dalam ruangan status Facebook. In Jurnal Komunikasi - Malaysian Journal of Communication, 31 (2), 151 168.

Petrey, S. (1990). Speech Acts and Literary Theory. New York: Routledge.

Searle, J. R. (1969). Speech acts: an essay in the philosophy of language. Cambridge: Cambridge University Press.

Searle, J. R. (1979). Expression and Meaning: Studies in the Theory of Speech Acts. Cambridge: Cambridge University Press.

Searle, J. R \& Vanderveken, D., (1985), Foundations of Illocutionary Logic. Cambridge: Cambridge University Press.

Rohaidah Haron. (2004). Perbicaraan di Mahkamah Syariah: Suatu Analisis. Master Dissertation. Universiti Malaya.

Ruth Ong Lok Tik. (2005). Analisis lakuan komunikatif pemandu pelancong semasa bertugas. In Jurnal Bahasa, 5 (4), 109-146.

Wan Robiah Meor Osman, Hamidah Abdul Wahab \& Siti Marina Kamil. (2010). Penggunaan bahasa dalam sesi kaunseling dari sudut lakuan bahasa. In Jurnal Bahasa 10 (1), 54-73. 